\title{
PENGARUH FAKTOR BIOLOGI TERHADAP GIZI KURANG ANAK USIA 6-11 BULAN DIKABUPATEN CILACAP
}

\author{
Majestika Septikasari \\ STIKES Al-Irsyad Al-Islamiyyah Cilacap, Jawa Tengah, Indonesia \\ majestika86@gmail.com
}

\begin{abstract}
ABSTRAK
Kekurangan gizi pada usia balita dapat menyebabakan terganggunya pertumbuhan fisik, perkembangan mental, menurunnya kecerdasan, bahkan dapat menjadi penyebab kematian. Penelitian ini bertujuan untuk menganalisis pengaruh LILA ibu awal kehamilan, berat badan bayi baru lahir, keberhasilan ASI eksklsusif dan asupan MP-ASI terhadap kejadian gizi kurang pada anak usia 6-11 bulan. Penelitian ini menggunakan desain studi analitik observassiaonal dengan pendekatan kasus kontrol. Pengambilan sampel menggunkan teknik fixed disease sampling sejumlah 144 sampel, terdiri dari 72 kasus dan 72 kontrol. Analisis dilakukan secara univariat dan bivariat menggunakan uji chi square. Hasil penelitian menunjukan adanya pengaruh kuat antara berat badan bayi baru lahir $(\mathrm{p}=0.009 ; \mathrm{OR}=10.14)$ dan asupan MP-ASI ( $\mathrm{p}=0.002 ; \mathrm{OR}=3.37)$ terhadap kejadian gizi kurang anak usia 6-11 bulan. Sedangkan LILA ibu awal kehamilan ( $\mathrm{p}=0.019$; $\mathrm{OR}=2.60)$ dan keberhasilan ASI eksklusif $(\mathrm{p}=0.004 ; \mathrm{OR}=2.67)$ berpengaruh sedang terhadap kejadian gizi kurang anak usia 6-11 bulan. Kesimpulan penelitian yaitu LILA ibu awal kehamilan, berat badan bayi baru lahir, keberhasilan ASI eksklsusif dan asupan MP-ASI secara signifikan berpengaruh terhadap kejadian gizi kurang anak usia 6-11 bulan di Kabupaten Cilacap.
\end{abstract}

Kata kunci: Gizi kurang, LILA, berat lahir, ASI ekkslusif, MP-ASI

\section{ABSTRACT}

Malnutrition among under-fives lead to disruption of physical growth, mental development, decreased intelligence, even be the cause of child's death. This study examined the influence of MUAC in early pregnancy, newborn weight, exclusive breastfeeding and complementary food intake toward underweight among children aged 6-11 months. Type of study is an analytic observational case control study. Data collected from 144 children used fixed diseases sampling consisted of 72 cases and 72 controls. Data analysis are univariate and bivariate with the chi square test. The results showed a strong effect between the newborn weight $(p=0.009 ;$ OR $=10.14)$ and the complementary food intake $(p=0.002$; $O R=3.37)$ on the incidence of underweight children aged 6-11 months. While MUAC in early pregnancy $(p=0.019 ; O R=2.60)$ and exclusive breastfeeding ( $p$ $=0.004 ; O R=2.67)$ were sufficiently influential on the incidence of underweight children aged 6-11 months. MUAC in early pregnancy, newborn's weight, exclusive breastfeeding and complementary food intake have significantly affected the incidence of underweight children aged 6-11 months in Cilacap

Key word: malnutrition, MUAC, newborn weight, breastfeeding, complementary food

\section{PENDAHULUAN}

Persoalan gizi anak merupakan salah satu permasalahan yang masih

menjadi perhatian dalam $\begin{array}{r}\text { upaya } \\ \text { manusia }\end{array}$
pembangunan
Indonesia.(Saputra dan Nurrizka,


2012) Berdasarkan data riset kesehatan dasar (Riskesdas) tahun 2013, prevalensi gizi buruk anak usia dibawah lima tahun (balita) mencapai angka $5.7 \%$ sedangkan balita dengan gizi kurang sebesar $13.9 \%$. (Kemenkes RI, 2015). Kondisi kekurangan gizi pada balita tidak hanya berdampak pada terganggunya pertumbuhan fisik tetapi juga berpengaruh pada perkembangan mental serta menurunkan kecerdasan, bahkan meningkatkan risiko kematian pada anak (Bappenas, 2013). Meningkatnya risiko kematian pada anak akibat gizi kurang dikarenakan secara signifikan gizi kurang berhubungan dengan meningkatnya risiko penyakit infeksi seperti infeksi pernafasan akut dan diare (Rabbidan Karmaker, 2014). Menurut World Health Organization (WHO) pada tahun 2002 gizi buruk menyebabkan $54 \%$ kematian pada balita (Putri et al., 2015).

Status gizi balita dapat dipengaruhi oleh faktor biologi yaitu status gizi ibu prahamil, berat badan bayi baru lahir, keberhasilan ASI eksklsusif dan asupan nutrisi yang adekuat. Ibu yang mengalami kurang energi kronis (KEK) pada masa kehamilan akan berdampak pada status gizi janin yang dipresentasikan oleh berat badan lahir rendah (BBLR) (Karima dan Achadi, 2012). Anak dengan riwayat BBLR berisiko 3.34 kali lebih besar untuk mengalami status gizi kurang dibandingkan dengan yang tidak mengalami BBLR (Arnisam, 2007). Secara langsung status gizi anak dipengaruhi oleh asupan nutrisi. Pemberian ASI eksklusif selama 6 bulan di lanjutkan dengan pemberian makanan pendamping ASI (MP-ASI) sampai dengan dua tahun dapat menurunkan risko gizi kurang pada anak (Lepita et al., 2009).

Kabupaten Cilacap merupakan salah satu dari tiga kawasan industri utama di Jawa Tengah. Berdasarkan data Riskesdas 2013, sebanyak 4\% balita di Kabupaten Cilacap mengalami gizi buruk dan $13.4 \%$ mengalami gizi kurang. Hal tersebut menjadikan Kabupaten Cilacap berada pada urutan 17 dari 35 Kabupaten dengan kasus gizi buruk terbanyak dengan persentase kasus yang tidak jauh dari persentase kasus secara nasional. berbagai upaya perbaikan gizi telah dilakukan namun belum menunjukan hasil yang signifikan hal initampak dari tren kejadian gizi kurang pada anak usia 6 sampai 11 bulan di Kabupaten Cilacap yang tidak banyak mengalami penurunan dimana pada tahun 2014 terdapat 152 kasus gizi kurang, 2015 sebanyak 158 kasus dan pada bulan Januari 2016 sebanyak 150 kasus.

\section{METODE PENELITIAN}

Penelitian ini merupakan penelitian studi analitik observassiaonal dengan pendekatan kasus control. Penelitian dilakukan di Kabupaten Cilacap dari bulan Januari sampai dengan Juli 2016. Populasi pada penelitian ini adalah seluruh anak usia 6-11 bulan di Kabupaten Cilacap pada bulan Januari tahun 2016 yaitu sebesar 14.728 anak. Pengambilan sampel menggunkan teknik fixed disease sampling dengan besar sampel sebanyak 144 sampel yang terdiri dari 72 kasus dan 72 kontrol. Sampel diambil pada 4 Puskesmas dengan kejadian gizi kurang anak usia 6-11 bulan terbanyak di Kabupaten Cilacap. Sampel harus memiliki buku KIA yang mencantumkan riwayat kehamilan (LILA ibu awal kehamilan) dan riwayat persalinan (berat badan 
bayi baru lahir) serta tidak dalam kondisi sakit/diare. Data status gizi anak diperoleh melalui penimbangan dimana berat badan dirubah dalam bentuk Z-score. LILA ibu awal kehamilan dan berat badan bayi baru lahir diperoleh melalui studi dokumentasi buku KIA sedangkan data keberhasilan ASI ekkslusif dan asupan MP-ASI diperoleh melalui kuesioner. Analisis data yang dilakukan meliputi analisa univariat dan bivariat dengan uji chi square. Penyajian data dalam bentuk tabel dan disertai narasi

\section{HASIL DAN PEMBAHASAN}

Hasil penelitian yang ditunjukan pada tabel 1 sebanyak $23.65 \%$ subjek penelitian memiliki riwayat ibu dengan KEK diawal kehamilan. Subjek penelitian dengan riwayat BBLR hanya sebesar $6.9 \%$. sebagian besar subjek penelitian $(56,35 \%)$ tidak berhasil ASI eksklusif dan $71.5 \%$ subjek penelitian tidak mendapat MP-ASI yang tidak adekuat.

Berdasarkan hasil uji statistik pada tabel 2, LILA ibu awal kehamilan $(\mathrm{OR}=2.60 ; \mathrm{p}=0.019)$, berat badan bayi baru lahir $(\mathrm{OR}=10.14 ; \mathrm{p}=0.009)$, keberhasilan ASI eksklusif $(\mathrm{OR}=2.66$; $\mathrm{p}=0.004)$ dan asupan MP-ASI $(\mathrm{OR}=3.37 ; \mathrm{p}=0.002)$ berpengaruh secara signifikan terhadap status gizi anak usia 6-11 bulan. Ibu dengan KEK akan meningkatkan risiko kejadian gizi kurang pada anak usia 6-11 bulan sebesar 2.6 kali. Bayi yang lahir dengan BBLR akan meningkatkan risiko kejadian gizi kurang pada anak usia 6-11 bulan sebesar 10 kali. ASI eksklusif yang tidak berhasil akan meningkatkan risiko kejadian gizi kurang pada anak usia 6-11 bulan sebesar 2.7 kali. Asupan MP-ASI yang tidak adekuat akan meningkatkan risiko kejadian gizi kurang pada anak usia 6-11 bulan sebesar 3.4 kali.

Tabel 1 Distribusi Frekuensi

\begin{tabular}{lcc}
\hline Variabel & $\mathrm{n}$ & $\%$ \\
\hline $\begin{array}{l}\text { Variabel Independen } \\
\text { LILA ibu awal } \\
\text { kehamilan }\end{array}$ & & \\
$\begin{array}{l}\text { a. KEK } \\
\text { b. Tidak KEK }\end{array}$ & 34 & 23.6 \\
$\begin{array}{l}\text { Berat badan bayi baru } \\
\text { lahir }\end{array}$ & 110 & 76.4 \\
a. BBLR & & \\
b. Normal & 10 & 6.9 \\
Keberhasilan ASI & 134 & 93.1 \\
eksklusif & & \\
a. Tidak eksklusif & 81 & 56.3 \\
b. Eksklusif & 63 & 43.7 \\
$\begin{array}{l}\text { Asupan MP-ASI } \\
\text { a. Tidak adekuat }\end{array}$ & 103 & 71.5 \\
b. Adekuat & 41 & 28.5 \\
Variabel Dependen & & \\
Status gizi anak & & \\
a. Gizi Kurang & 72 & 50 \\
b. Gizi baik & 72 & 50 \\
\hline Sumbr
\end{tabular}

Sumber: data primer diolah, 2016

LILA ibu yang kurang dari 23.5 $\mathrm{cm}$ merupakan salah satu idikator kondisi kurang energi kronis (KEK). Ukuran plasenta pada ibu dengan KEK akan lebih kecil dibandingkan ibu yang tidak mengalami KEK. KEK pada ibu hamil akan menyebabkan berkurangnya ekspansi volume darah yang mengakibatkan pemompaan darah dari jantung (cardiac output) tidak tercukupi sehingga aliran darah ke plasenta menjadi berkurang. Kondisi tersebut berdampak pada ukuran plasenta yang tidak optimal yang selanjutnya mengakibatkan pengurangan distribusi zat gizi ke janin dan menyebabkan pertumbuhan janin terhambat. Hal tersebut sesuai dengan penelitian yang dilakukan di Sawahlunto-Sijujung pada tahun 2007 dimana diperoleh hasil ibu yang mengalami KEK berisiko melahirkan bayi dengan BBLR 4,8 kali lebih besar 
dari pada ibu yang tidak mengalami KEK (Ariyani et al., 2012).

Anak yang lahir dengan riwayat BBLR, berisiko lebih besar mengalami gangguan pada sistem syaraf sehingga pertumbuhan dan perkembanganya akan lebih lambat dibandingkan anak yang lahir dengan berat badan normal. Bayi dengan BBLR lebih rentan terhadap penyakit infeksi sehingga apabila tidak didukung dengan pemberian nutrisi yang adekuat maka risiko mengalami gizi kurang atau gizi buruk di kemudian hari akan lebih besar.
Ulee Kareng, Banda Aceh dimanan hasil penelitian menunjukan balita dengan riwayat BBLR mempunyai risiko 3,34 kali lebih besar untuk mengalami status gizi kurang dibandingkan dengan yang tidak memiliki riwayat BBLR (Arnisam, 2007).

ASI merupakan makanan paling ideal untuk bayi baru lahir sampai dengan 6 bulan karena mengandung nutrisi esensial untuk pertumbuhan dan perkembangan bayi. ASI tidak hanya mengandung zat-zat bernilai gizi tinggi yang dibutuhan untuk

Tabel 2 Analisis Bivariat

\begin{tabular}{|c|c|c|c|c|c|c|c|c|}
\hline \multirow{3}{*}{$\begin{array}{l}\text { Variabel } \\
\text { Independen }\end{array}$} & \multicolumn{4}{|c|}{ Status Gizi Anak } & \multicolumn{4}{|c|}{ CI $(95 \%)$} \\
\hline & \multicolumn{2}{|c|}{$\begin{array}{c}\text { Gizi } \\
\text { Kurang }\end{array}$} & \multicolumn{2}{|c|}{ Gizi Baik } & \multirow[t]{2}{*}{ OR } & \multirow{2}{*}{$\begin{array}{c}\text { Batas } \\
\text { Baw } \\
\text { ah }\end{array}$} & \multirow[t]{2}{*}{$\begin{array}{c}\text { Batas } \\
\text { Atas }\end{array}$} & \multirow[t]{2}{*}{$\mathrm{p}$} \\
\hline & $\mathrm{n}$ & $\%$ & $\mathrm{n}$ & $\%$ & & & & \\
\hline $\begin{array}{l}\text { LILA ibu awal } \\
\text { kehamilan }\end{array}$ & & & & & 2,60 & 1,16 & 5,86 & 0,019 \\
\hline KEK & 23 & 67,6 & 11 & 32,4 & & & & \\
\hline Tidak KEK & 49 & 44,5 & 61 & 55,5 & & & & \\
\hline $\begin{array}{l}\text { Berat badan bayi } \\
\text { baru lahir }\end{array}$ & & & & & 10,14 & 1,25 & 82,30 & 0,009 \\
\hline BBLR & 9 & 90 & 1 & 10 & & & & \\
\hline Normal & 63 & 47 & 71 & 53 & & & & \\
\hline $\begin{array}{l}\text { Keberhasilan } \\
\text { ASI eksklusif }\end{array}$ & & & & & 2,66 & 1,35 & 5,25 & 0,004 \\
\hline Tidak eksklusif & 49 & 60,5 & 32 & 39,5 & & & & \\
\hline Eksklusif & 23 & 36,5 & 40 & 63,5 & & & & \\
\hline Asupan MP-ASI & & & & & 3,37 & 1,55 & 7,35 & 0,002 \\
\hline Tidak adekuat & 60 & 58,3 & 43 & 41,7 & & & & \\
\hline Adekuat & 12 & 29,3 & 29 & 70,7 & & & & \\
\hline
\end{tabular}

Sumber: data primer diolah, 2016

Penelitian di Brazil menunjukan bahwa riwayat BBLR secara signifikan berhubungan dengan gizi kurang, stunting dan wasting pada balita (Rosha et al., 2013). Penelitian tersebut sejalan dengan penelitian di pertumbuhan dan perkembangan syaraf dan otak bayi tetapi ASI juga mengandung zat kekebalan yang akan melindungi bayi, sehingga bayi tidak mudah sakit. Colostrum dalam ASI merupakan antibodi terbaik yang dapat melindungi bayi dari infeksi dan 
penyakit. ASI ekslusif juga berhubungan dengan status gizi balita. Hal ini tampak pada penelitian di Bangladesh dimana kejadian gizi kurang pada balita lebih banyak terjadi pada kelompok dengan durasi pemberian ASI kurang dari 24 bulan (Rabbi dan Karmaker, 2014). Berdasarkan penelitian yang dilakukan di Padang Barat didapatkan hasil Bayi yang mendapat ASI ekslusif $80 \%$ berstatus gizi normal (Nilakesuma et al., 2015). Lamanya durasi pemberian ASI saja juga berpengaruh positif terhadap pertumbuhan balita yang diukur berdasarkan persen terhadap median BB/U dan BB/TB baku rujukan WHO-NCHS (Lepita et al., 2009).

Setelah usia 6 bulan ASI hanya mencukupi kebutuhan nutrisi sebanyak $60 \%$ sehingga setelah 6 bulan perlu diberikan makanan pendamping ASI (MP-ASI) sampai dengan anak berusia 2 tahun. MP-ASI harus mencakup semua zat gizi yang dibutuhkan antara lain karbohidrat, protein, lemak vitamin, mineral dan air dengan memperhatikan kebersihan dan keamanannya bagi bayi. Pemberian MP-ASI harus memperhatikan beberapa hal antara lain waktu yang tepat. Pemberian MPASI yang terlalu dini dapat menyebabkan gangguan pencernaan pada bayi karena secara fisiologis saluran pencernaan bayi belum siap untuk makanan padat sehingga dapat terjadi diare atau konstipasi. Selain itu pemberian MP-ASI yang terlalu dini juga meningkatkan risiko obesitas, alergi, dan menurunnya imunitas karena berkurangnya konsumsi ASI. MP-ASI juga tidak boleh diberikan terlalu lambat. Keterlambatan Ariyani DE, Achadi EL, dan Irawati A. Validitas Lingkar Lengan Atas Mendeteksi Risiko pemberian MP-ASI akan berdampak pada tidak terpenuhinya kebutuhan nutrisi anak. Berdasarkan beberapa studi yang telah dilakukan tampak jelas terlihat hubungan antara pemberian MP-ASI dengan status gizi balita. Penelitian yang dilakukan di wilayah kerja puskesmas Gedongtengen Yogyakarta menunjukan hubungan yang bermakna antara pola pemberian MP-ASI dan status gizi balita usia 6-24 bulan (Septiana et al., 2010). Hal tersebut serupa dengan penelitian yang dilakukan di Kelurahan Setabelan Kota Surakarta dimana hasil penelitian menunjukan terdapat hubungan bermakna antara pemberian MP-ASI dengan status gizi bayi usia 6-24 bulan (Wardhani, 2015).

\section{KESIMPULAN DAN SARAN}

Terdapat pengaruh kuat antara berat badan bayi baru lahir $(\mathrm{p}=0.009$; $\mathrm{OR}=10.14$ ) dan asupan MP-ASI $(\mathrm{p}=0.002 ; \mathrm{OR}=3.37)$ terhadap kejadian gizi kurang anak usia 6-11 bulan. Sedangkan LILA ibu awal kehamilan $(\mathrm{p}=0.019 ; \mathrm{OR}=2.60)$ dan keberhasilan ASI eksklusif $(p=0.004 ; \quad O R=2.67)$ berpengaruh sedang terhadap kejadian gizi kurang anak usia 6-11 bulan.

\section{SARAN}

Perlu adaya peningkatan pelayanan antenatal care baik dari segi sumber daya manusia maupun sarana prasarana dalam upaya meningkatkan kesejahteraan bayi selama proses kehamilan sehingga bayi dapat dilahirkan dengan kondisi normal. dapat teridentivikasi dengan lebih cermat

\section{DAFTAR PUSTAKA}

Kekurangan Energi Kronis pada Wanita Indonesia. Jurnal 
Kesehatan Masyarakat Nasionl. 2012; 7( 2): 83-89

Arnisam. Hubungan Berat Badan Lahir Rendah (BBLR) dengan Status Gizi Anak :Usia 6-24 Bulan. 2007. [Diakses 27 Januari 2016]. Available at: http://etd.repository.ugm.ac.id.

Babatunde RO, Olagunju FI, Fakayode SD, and Sola-Ojo FE. Prevalence and Determinants of Malnutrition among Under Five Children of Farming Households in Kwara State, Nigeria. Journal of Agricultural Science. 2011; 3 (3):173-181

Bappenas.. Periode Emas pada 1000 Hari Pertama Kehidupan. Buletin 1000 Hari Pertama Kehidupan. 2013; 1 (1): 1-4

Correia LL, Silvia AC, Campos JS, Andrade FM, Machando MMT, Lindsay AC, Leite AJM et al,. Prevalence and Determinants of Child Undernutrition and Stunting in Semiarid Region of Brazil. Revista de Saúde Pública. 2014; 48 ): 19-28

Cunha AJLA, Leite AJM, and Almeida IS. The Pediatrician's Role in The First Thousand Days of The Child: The Pursuit of Healthy Nutrition and Development. Jornal de Pediatria. 2015; 91 (6): 44-51

Depkes RI. Situasi Kesehatan Anak Balita di Indonesia. InfoDatin 8 April; 2015.

Karima K \& Achadi EL. Status Gizi Ibu dan Berat Badan Lahir Bayi. Jurnal Kesehatan Masyarakat Nasional. 2012; 7(3): 111-119.

Krisnatuti D. Menyiapkan Makanan Pendamping ASI. Jakarta: Puspa Swara; 2008.

Lepita, Sukandar H dan Wirakusumah FF. Evaluasi Pengaruh Lamanya Pemberian ASI Saja terhadap
Pertumbuhan Anak. Bandung Medical Journal. 2009; 41 (1): 27-31.

Nilakesuma A, Jurnalis YD, dan Rusjdi SR. Hubungan Status Gizi Bayi dengan Pemberian ASI Eksklusif, Tingkat Pendidikan Ibu dan Status Ekonomi Keluarga di Wilayah Kerja Puskesmas Padang Pasir. Jurnal Kesehatan Andalas. 2015; 4 (1): 37-44

Putri RF, Sulastri D, dan Lestari Y. Faktor-Faktor yang Berhubungan dengan Status Gizi Anak Balita di Wilayah Kerja Puskesmas Nanggalo Padang. Jurnal Kesehatan Andalas. 2015; 4 (1): 254-261

Rabbi AMF \& Karmaker SC. Determinants of Child Malnutrition in Bangladesh - A Multivariate Approach. Asian Journal of Medical Sciences. 2014; 6 (2): 85-90

Roesli U. Panduan Inisiasi Menyusu Dini Plus ASI Eksklusif. Jakarta: Pustaka Bunda; 2012.

Rosha BC, Putri DSK, dan Putri IYS. Determinan Status Gizi Pendek Anak Balita dengan Riwayat Berat Badan Lahir Rendah (BBLR) di Indonesia (Analisis Data Riskesdas 2007-2010). Jurnal Ekologi Kesehatan. 2013; 12 (3): 195-205

Saputra W \& Nurrizka RH. Faktor Demografi dan Risiko Gizi Buruk dan Gizi Kurang. Makara Journal of Health Research. 2012; 16 (2): 95-101

Septiana R, Djanah RSN, dan Djamil MD. Hubungan antara Pola Pemberian Makanan Pendamping ASI (MP-ASI) dan Status Gizi Balita usia 6-24 Bulan di Wilayah Kerja Puskesmas Godongtengen 
Yogyakarta. Jurnal Kesehatan

Masyarakat. 2010; 4 (2): 118-

124

Wardhani GK. Hubungan pemberian makanan pendamping asi dengan status gizi bayi usia 6-24 bulan di kelurahan setabelan Kota Surakarta. 2015. [Diakses 30 Mei 2016]. Available at: https://digilib.uns.ac.id 